\title{
ISLAMIC PERSONALIZATION AS THE BASIS OF RIGHT CLAIM SUBMISSION IN RELIGIOUS COURT
}

\author{
Rahadi Wasi Bintoro \\ Faculty of Law Universitas Jenderal Soedirman, Indonesia \\ E-mail: rahadiwasibintoro@gmail.com \\ Abd. Shomad \\ Faculty of Law Universitas Airlangga, Indonesia \\ Masruhan \\ Universitas Islam Negeri Sunan Ampel, Indonesia
}

\begin{abstract}
Law Amendment of Religious Court Year 2006 brought revolutionary change toward the competences of religious court. Law of Religious Court mentioned that Religious Court is only for Muslims. Furthermore, several questions appear such as are they only Muslims who are able to have any case in Religious Court, how is about people who are non-Muslim or how is about other law subjects in form of legal entity whether they can have any case or not. This paper discusses the subjects and the objects of right claim in religious court. Based on the analysis, the judiciary for law subjects who are Muslims or obey to Islamic laws in muamalah matters is done based on Islamic principles. That is what is called as Islamic personalization. This needs to be emphasized that Islamic personalization is an absolute competence in which if it is broken, it will cause right claim become NO (niet ontvankelijke verklaard).
\end{abstract}

Keywords: Islamic personalization, right claim, religious court

\section{Abstrak}

Perubahan UU Peradilan Agama pada tahun 2006 membawa perubahan yang revolusioner terhadap kewenangan yang dimiliki oleh peradilan agama. UU Peradilan Agama menyebutkan bahwa Peradilan Agama berlaku bagi orang yang beragama Islam. Muncul pertanyaa kemudian, apakah hanya orang yang beragama Islam saja yang dapat berperkara di Peradilan Agama, bagaimana dengan orang yang tidak beragama Islam atau bagaimana dengan subyek hukum laianya dalam bentuk badan hukum, apakah mereka dapat berperkara juga. Tulisan ini akan membahas tentang subyek dan obyek tuntutan hak di peradilan agama. Berdasarkan analisis, peradilan bagi subyek hukum yang beragama Islam atau menundukan diri pada hukum Islam dalam permasalahan muamalah untuk diselesaikan dengan mendasarkan pada prinsip-prinsip syariah. Inilah yang kemudoian disebut sebagai personalitas keislaman. Hal ini perlu ditegaskan, mengingat personalitas Keislaman merupakan kompetensi absolut yang apabila dilanggar akan mengakibatkan tuntutan hak menjadi NO (niet ontvankelijke verklaard).

Kata Kunci: personalitas keislaman, tuntutan hak, peradilan agama

\section{Introduction}

The advancement of sharia economic system in Indonesia can be measured by the advancement of Islamic banking as part of sharia economic system since 1998 till now $^{1}$ and it ra-

Liky Faisal, "Politik Ekonomi Islam Dalam Pembangunan Ekonomi Nasional Di Indonesia", Jurnal Asas, Vol 5 No. 2, 2013, Lampung: IAIN Raden Indtan, p. 1-2; Nevi Has- pidly develops ${ }^{2}$ until international level. ${ }^{3}$ It results another consequence which is if there is

nita, "Politik Hukum Ekonomi Syari'ah Di Indonesia", Legitimasi, Vol. 1 No. 2, January-June2012, Banda Aceh: Islamic Faculty of IAIN Ar-Raniry, page 260.

2 Muhammad Syafi'i Antonio, “Membangun Ekonomi Islam di Indonesia", Varia Peradilan, Year XXI No. 245 April 2006, Jakarta: IKAHI, p. 25; Ali Mansyur, "Aspek Hukum Perbankan Syariah dan Implementasinya di Indonesia", Jurnal Dinamika Hukum, Vol. 11 Edisi khusus, 2011, Pur- 
dispute in conducting sharia economic activities. ${ }^{4}$ Even until now there is still debate regarding the competences of Religious Court, but at least, there is already step forward to strengthen the role of Religious Court as the place for Muslims in solving their problem in law. For instance, before the Law Amendment of Religious Court Year 2006 through Law Number 3 Year 2006 about Law Amendment Number 7 Year 1989 on Religious Court and Law Number 50 Year 2009 on second Law Amendment Number 7 Year 1989 on Religious Court, in certain civil law cases, there is still law choice whether those cases are going to be solved in General Court or Religious Court. However, through Law Number 3 Year 2006 and Law Number 50 Year 2009, all the disputes happen among Muslims become the competence of Religious Court as it is regulated in Article 1 Law Number 50 Year 2009 and Article 2 Law Number 3 Year 2006.

The stipulations are interesting to be reviewed deeper, especially about the law subject in the case that is being the competence of Religious Court. It is caused by the stipulation in Law of Religious Court which stated that only Muslims who are able to have any case in Religious Court. Then, how is about others who are non-Muslims and also how is about law subject in the form of legal entity. Besides, regarding the law subject that is able to have case in Religious Court, the object of the case which becomes the competence of Religious Court is interesting to be discussed, especially about whether all disputes done by Muslims becomes

wokerto: Law Faculty of Universitas Jenderal Soedirman, page 69; Tim Lindsey, "Between Piety and Prudence: State Syariah and the Regulation of Islamic Banking in Indonesia", Sydney Law Review, Vol. 34 No. 107, 2012, Sydney: Sydney Law School-the University of Sydney, page 111.

3 Mehmet Asutay, "Conceptualisation Of The Second Best Solution In Overcoming The Social Failure Of Islamic Banking And Finance: Examining The Overpowering Of Homo-islamicus By Homoeconomicus", IIUM Journal of Ecnomics and Managemen, Vol. 15, No. 2, 2007, Selangor: The International Islamic University Malaysia, page 168; see also M. Raquibuz Zaman and Hormoz Movassaghi, Islamic Banking A Performance Analysis “, The Journal of Global Business, Vol. 12, No. 22, Spring 2001, page 38.

4 Khopiatuziadah, "Kajian Yuridis Penyelesaian Sengketa Perbankan Syariah", Jurnal Legislasi, Vol. 10 No. 3, September 2013, Jakarta: DJPP of Justice and Human Rights Ministry, page 279. the competence of Religious Court or only cases whose law based on Islamic laws become the competence of Religious Court. Those things must be paid attention in arranging right claim in Religious Court in order to prevent Niet ontvankelijke verklaard (NO) dropped by the verdict.

\section{Discussion}

Before the amendment of Law Number 7 Year 1989, Religious Court only has competence to deal with the disputes in family law (alahwal al-shakhsiyah) such as marriage, inheritance, testament, and grant, that are done based on Islamic laws, as well as waqf and shodaqah. Then, by considering the dynamics of Islamic economic development that rapidly ${ }^{5}$ grows in society, there is Law Amendment through Law Number 3 Year 2006 and Law Number 50 Year 2009.

Basically, Religious Court has two competences, relative competentie which is the competence of court that basically lays on jurisdiction, and absolute competentie that is the competence given by legal entity based on law. In this case, it concerns on the kind of case and the level of court.

The stipulation of Article 49 Number 3 Year 2006 has given limitation to all kinds of case that become its absolute competences, where there are three new additional competences for Religious Court, such as: alms, infaq and sharia economics. Sharia economics based on the explanation of the letter (i) Article 49 is the action or business activity that is conducted based on Islamic principles, including: Sharia Bank; Sharia Micro Finance Institution; Sharia Insurance; Sharia Reinsurance; Sharia Mutual Funds; Sharia Bonds and Sharia Medium Term Securities; Islamic Securities; Islamic Financing; Sharia Pawnshops; Pension Fund of Sharia Financial Institution; and Sharia Business.

The absolute competences of Religious Court can be explained briefly as follows:

\footnotetext{
Eman Superman, "Perkembangan Doktrin Penyelesaian Sengketa di Indonesia"; Jurnal Penegakan Hukum. Vol. 3 No. 2, July 2006, Bandung: Law Division of Law Faculty of Universitas Padjadjaran, page 21-35;
} 
190 Jurnal Dinamika Hukum Vol. 17 No. 2, May 2017

First, marriage. Marriage under the provision of Article 1 Law Number 1 Year 1974 is:

"Marriage is the external and internal bond between a man and a woman as a couple of husband and wife in order to form a happy, everlasting family or household based on the belief in one and only God."

Marriage is part of family law. Cases in the field of marriage that are under the competence of Religious court in the explanation of Article 49 letter (a) Law Number 3 Year 2006 reiterated again, namely:

The definition of "marriage" shall be matters regulated in or based on applicable marriage laws implemented according to Islamic principle, among others:

1. permission to have more than one wife;

2. permission to establish marriage for persons who are less than 21 years old, in the case of guardian parents, or family in a straight line there is a difference of opinion;

3. marriage dispensation;

4. prevention of marriage;

5. marriage rejection by the Marriage Officer;

6. cancellation of marriage;

7. lawsuit of negligence on the obligations of the husband and wife;

8. divorce due to talaq;

9. divorce lawsuit;

10. joint settlement;

11. children custody;

12. the mother may bear the cost of education and child care when the father does not obey it;

13. the determination of the obligation to provide the cost of living by the husband to the ex-wife or the determination of an obligation for the exwife;

14. verdict on the validity of a child;

15. verdict on the revocation of parental control;

16. revocation of guardianship;

17. appointment of another person as a guardian by court in the event of the guardian's power being revoked;

18. appointment of a guardian in the case of a child who is less than 18 years old who is left behind by both parents;

19. the formation of a compensation liability for the property of a child under his control;

20. determination of the origin of a child and the adoption of a child based on Islamic law;

21. verdict on the matter of refusal to provide information for mixed marriage;

22. statement concerning the validity of marriage that occurred before Law Number 1 Year 1974 on Marriage and it is implemented according to other regulations.

Based on these provisions, it is clear that marriage cases which are the competence of Religious Court are marriage cases committed by Muslims of course based on Islamic law.

Second, inheritance. Explanation of Article 49 letter (b) stipulates the case in the field of inheritance which is the competence of religious court, which are: Determination of who the heir is; Determination of heritage properties; Determination of part of each heir; Carry out the distribution of the heritage properties; The court's decision on a person's application regarding the determination of who the heir is, and the determination of their parts. It should be emphasized that there is no choice of law in the case of inheritance as the case of inheritance that is being regulated in Law Number 7 Year 1989. For those who are Muslim, then the Islamic law of inheritance is applied for them and this case becomes the absolute competence of Religious court.

Third, testament. Testament in the explanation of Article 49 letter (c) is the act of a person providing an object or benefit to another person or institution/ legal entity that is applicable after the death of the giver. More detailed provisions are regulated in Presidential Instruction Number 1 Year 1991 on the Compilation of Islamic Laws $(\mathrm{KHI})$. In $\mathrm{KHI}$, the testament is placed in chapter $\mathrm{V}$, and it is governed by 16 articles. The basic provisions regulated therein are: the requirement of the person making the will/ testament, the property that is being testament, when the testament goes into effect, 
where the testament is done, how much the maximum testament could be given, how the position of the testament to the heir is, in the testament it must be clearly stated who the receiver of the properties of the testament is, when the testament is cancelled, testament of the investment proceeds, the revocation of testament, how if the property of the testament is shrinking, the testament exceeds one-third while the heir disagrees, where the testament is kept, how if the testament is revoked, how if the heir of the testament is already dead, testament in the conditions of war, testament on the journey, to whom the testament is not allowed, for whom the testament is not valid, how much the wajibah testament that is mandatory for the adoptive parents, and how much the wajibah testament which is mandatory for the adopted child.

Fourth, grant. Grant is a voluntary and non-compensatory gift of a person or legal entity to another person or legal entity to own. Grant is also not regulated in detail in Law of Religious Court. Grant is broadly regulated in the Compilation of Islamic Laws in chapter VI, and it is only organized into five articles. Generally these articles contain: The subject of grant law, the amount of the grant, where the grant is made, the granted property, the parent's grant to the child, when the grant should be approved by the heirs, and grants made outside the territory of the Republic of Indonesia.

Fifth, waqf. Waqf according to Article 1 Law number 41 Year 2004 regarding Waqf is a waqif's legal act to separate and/or hand over some of his property to be exploited forever or for a certain period of time in accordance with his interests for the purposes of worship and/or general welfare according to Islamic law.

Sixth, alms. Alms is a property that must be set aside by a Muslim or a legal entity owned by Muslim in accordance with the provisions of Islamic law to be given to those who deserve to receive it. Regulation concerning alms has been regulated separately in Law Number 38 Year 1999 State Gazette Number 164 Year 1999 regarding Alms Management. Broadly, the contents of this Law are: The Government consi- ders that it is necessary to intervene in the field of alms, which includes: protection, guidance and service to muzakki, mustahiq and amil of alms; the purpose of alms management; alms management organization; collection of alms; utilization of alms; supervision of alms management; and sanctions against violations of alms management regulations.

Seventh, infaq. Infaq is one's act to give others in order to cover needs of foods, drinks, donation, blessings or giving others something sincerely because of Allah Subhanahu Wata'ala. The basic law of infaq is Quran and Hadist.

Eighth, shodaqoh. Shodaqoh is an action to give something to others or institutions spontaneously and voluntarily without being limited to time and certain amount of money by hoping to receive blessings and rewards from Allah. Similar to infaq, shadaqoh is arranged in Quran and Hadist.

Ninth, sharia economics. Sharia economics is defined as an action or business activity which is held according to Islamic principles. The authority is done by Islamic Bank; Islamic Micro Finance Institution; Islamic Insurance; Islamic Reinsurance; Islamic Mutual Funds; Islamic Bonds and Islamic Medium Term Securities; Islamic Securities; Islamic Financing; Islamic Pawnshops; Pension Fund of Islamic Financial Institution; and Islamic Business.

Those nine cases belong to the absolute competence of Religious Court, if we take a look closely; the cases are those who are closely related to law and Islamic law. Therefore, cases which are not related to or based on Islamic Law, such as debts and receivables, trade, rent or other civil relationship do not belong to Islamic law.

In order to answer those discourses, there need to be an understanding on what is the philosophy related to the existence of Law of Religious Court and Law Amendment of Religious Court. Based on Article 1 Section (1) Number 50 Year 2009 on Religious Court, they should create justice for Muslims. Then, Article 2 Law Number 3 Year 2006 on arrangement of Religious Court, they are one of the actors of judicial power for Muslims who seek for justice re- 
lated to certain cases as mention in this Law. Based on those two laws, it is clear that Religious Court is meant for Muslims. The exclusivity possessed by Muslims cannot be separated with the influence of ideas and Islamic Laws themselves in Indonesia. Islamic laws applied in Indonesia, is not only applied in formal judicial, but it is also a positive law based on or because it is appointed by legislation. Islamic law in Indonesia has become living law among the people since it is a religion entity embraced by the majority of people to this day. Under amaliah dimension in several areas, it has become a part of tradition which is considered as holy. ${ }^{6}$ Therefore, sociologically and culturally, Islamic law is a law which flow and it is rooted deeply in the culture of society. Two of the factors are because of its flexibility and elasticity. Hence, it means that Islamic law belongs to autonomy law; nonetheless, the implementation is very applicable and acceptable with any kind of local culture.

The development of the competences of Religious Court is in line with the cases of life for Muslims since they become their sui generis. However, Indonesia is not a Muslim country; thus, the competences of Religious Court do not involve every aspect that Muslims have. It is only related to the cases of families (ahwal alsyakhsiyah) along with several muamalah cases (as arranged in Article 49 Law Number 3 Year 2006).

Hence, the addition of the competences of Religious Court is in line with law development and the need of people, especially Muslims. This is suitable with the statement of Eugien Ehrlich that "...a good law is the one which is suitable with law living among the society". ${ }^{7}$ Positive law will only be effective if it is in line with law living among the society; it is known as anthropology or culture pattern. David N. Schiff stated, “...law and regulations

6 Muhammad Kasim, "Organisasi Islam dan Pengaruhnya pada Hukum Islam di Indonesi', Jurnal ilmiah Al Syir'ah, Vol. 7 No. 1, 2009, Manado: Institute Agama Islam Manado available on website: http://journal.iain-manado.ac. id/index. php/JIS/article/view/59/53, accessed on March $2^{\text {nd }}, 2017$.

7 Soerjono Soekanto, 1985, Perspektif Teoritis Studi Hukum dalam Masyarakat, Jakarta: Rajawali, page 19. are interrelated, especially from social changes which happen very fast; therefore, individual interest in society needs to be accommodated in law regulations." He also stated that “...there is a relationship between behavioral patterns which turns into law form with real behavior from individual". Hence, under the perspective of sociology of law, it is not a surprise that there is an addition in the absolute competences of Religious Court since there need to be symmetrical balance between society's development with law regulations, so there will be no gap between problem with its way and problem solving. ${ }^{8}$ In the sense, society's development which necessitates the emersion of problem will be able to be solved through legal approach instead of illegally. However, the extension of competences is also in line with the theory of three elements law system by Friedman and behavioral pattern especially about legal substance. Friedman stated that legal substance is rule; norm and a person real behavioral pattern existed in a system. The substance also means produced product including verdict, new formed regulation. The substance also includes living law and not only those which exist in the book of law.

The explanation affirms that the extension of the absolute competence of Religious Courts is a necessity, since all the competences of Religious Court, either concerning marriage, inheritance, waqf, alms, or the issue of sharia economics, are something that has been attached to the Muslim community. In other words, Islamic law which has been the competence of Religious Court is being a living law, a law which lives and is practiced by society.

Thus, there is always a relationship between Muslims and the teachings of Islam and the enforcement of Islamic Law which later becomes the absolute competence of Religious Court. Therefore, it is inevitable that the legal relationship between Muslims must be settled by virtue of Islamic law even in the legal rela-

\footnotetext{
Adam Podgorecki dan Christopher J. Whelan "Sociological Approaches to Law", translated by Rnc. Widyaningsih and Kartasapoetra, 1987, Pendekatan Sosiologis Terhadap Hukum, Jakarta: Bina Aksara, page 253-287.
} 
tionship not explicitly using Islamic law as the basis of its legal relationship. Seeing the existence of the Religious Court as a legal structure is straight line to its competence as legal substance, if the legal structure is strong but the legal substance is weak, then it is like an hollow building that does not contain anything.

Muslims apply Islamic law and it becomes the competence of Religious Court. This is then called the Principle of Islamic Personalization. Those who are obeying and able to be obeyed to the power of Religious Court are Muslim. ${ }^{9}$ Muslim's faith becomes the basis of the court's competence within the religious court regardless seeing faith level.

The next question is whether the Religious Court only is only valid for legal subjects in the form of person only as referred to Article 1 section (1) Law number 50 Year 2009. Based on the explanation of Article 49 Law number 3 Year 2006, what is meant by "between persons in Islam" is any person or legal entity who voluntarily obeys to Islamic law on matters under the competence of a religious court. The explanation of Article 49 mentioned that the person and the Legal Entity as the legal subject who can claim the rights to Religious Court. Thus, legal subjects who can have case in Religious Court are not limited only to legal subjects of persons, but also to legal entities. The further question is whether it is only for Muslims or not. In order to answer this question, it should be noted that relationship between law and sharia economic practices in general, does not require to be done by Muslims only, non-Muslims can also do law relations with sharia economic practices such as Islamic banking, such as fundraising (Savings) as well as the distribution of public funds (buying and selling, leasing, borrowing) based on the Islamic principles. In this case, non-Muslims have voluntarily obeyed to Islamic Law as considered by the law. However, when seeing the cases thoroughly for example the practice of Islamic banking, which requires

Etika Rahmawati, “Telaah terhadap Asas Personalitas Keislaman Dikaitkan dengan Teori Receptio in Complexu”, Gloria Yuris, Vol 1 No. 2, 2013, Jakarta: Universitas Katolik Atma Jaya, p. 24.
Islamic principles as the basis of legal relationship, it brings the consequences for the people who want to implement legal relation in the field of Islamic banking in which they should obey to Islamic principles as the basis of legal relation. In this case, it can be said that submission to the Islamic principles is not voluntary but it is a necessity.

The next legal subject is in the form of legal entity. Islamic legal entities that exist in Law Number 3 Year 2006 can be classified into 4 (four) categories. ${ }^{10}$ First, legal entities which are established under the provisions of Islamic law, such as Alms Administrators Board, Institute of Alms Administrators, Baitul Maal, Nadzir Waqaf and so on; Second, legal entities in sharia economics such as Islamic banking, Islamic pawnshops and so on as mentioned in Article 49 letter h; Third, legal entities owned by Muslims; Fourth, other legal entities (ordinary legal entities) that conduct the business activities based on Islamic principles.

The determination of legal subjects and legal objects in submitting right claim ${ }^{11}$ in religious court must be clear and detailed. The unclear submission will result "unacceptable" verdict from judge (Niet Ontvankelijke verklaard).

\section{Conclusion}

Religious Court is a judiciary for Islamic law subjects or those who obey to Islamic law in muamalah matters that are solved based on Islamic principles. The increasing and the more complex absolute competence of Religious Court shows the higher needs of Muslims for the application of Islamic law in muamalah activities. It is expected that this condition is straight line to people's faith and devotion to Allah SWT. Islamic law as sui generis of Muslims be-

10 Mukti Arto, "Garis Batas Kekuasaan Peradilan Agama dan Pengadilan Negeri, Penerapan Asas Personalitas KeIslaman sebagai Dasar Penentuan Kekuasaan Peradilan Agama”, Varia Peradilan, No. 253 December 2006, page 20.

11 Lihat lebih lanjut dalam Rahadi Wasi Bintoro, "Tuntutan Hak dalam Persidangan perkara Perdata', Jurnal Dinamika Hukum, Vol. 10 No. 2, Mei 2010, Purwokerto: Fakultas Hukum Universitas Jenderal Soedirman, page 149 
comes the basis in implementing legal relations as well as attempting to overcome the dispute.

\section{References}

Antonio, Muhammad Syafi'i. "Membangun Ekonomi Islam di Indonesia". Varia Peradilan. Year XXI No. 245 April 2006. Jakarta: IKAHI;

Arto, Mukti. "Garis Batas Kekuasaan Peradilan Agama dan Pengadilan Negeri. Penerapan Asas Personalitas Kelslaman sebagai Dasar Penentuan Kekuasaan Peradilan Agama". Varia Peradilan. No. 253 December 2006;

Asutay, Mehmet. "Conceptualisation of The Second Best Solution In Overcoming The Social Failure Of Islamic Banking And Finance: Examining The Overpowering Of Homoislamicus By Homoeconomicus". IIUM Journal of Economics and Managemen. Vol. 15. No. 2. 2007. Selangor: The International Islamic University Malaysia;

Bintoro, Rahadi Wasi. "Sharia Business And The Challenge Of Dispute Settlement In Indonesian Religious Court". Problems of Legality. No. 133. 2016. Kharkiv: Yaroslav Mudryi National Law University;

Bintoro, Rahadi Wasi. "Tuntutan Hak dalam Persidangan perkara Perdata'. Jurnal Dinamika Hukum. Vol. 10 No. 2. May 2010. Purwokerto: Law Faculty of Universitas Jenderal Soedirman;

Faisal, Liky. "Politik Ekonomi Islam Dalam Pembangunan Ekonomi Nasional Di Indonesia”. Jurnal Asas. Vol. 5 No. 2. 2013. Lam-pung: IAIN Raden Intan;

Hasnita, Nevi. "Politik Hukum Ekonomi Syari'ah Di Indonesia". Legitimasi. Vol.1 No. 2. January-June 2012. Banda Aceh: Islamic Faculty of IAIN Ar-Raniry;

Kasim, Muhammad. "Organisasi Islam dan Pengaruhnya pada Hukum Islam di Indonesi'. Jurnal ilmiah Al Syir'ah. Vol. 7 No. 1. 2009. Manado: Institute Agama Islam Mna- do available on website: http://jour nal.iainmanado.ac.id/index.php/JIS/artic le/view/59/53. Accessed on March $2^{\text {nd }}$, 2017;

Khopiatuziadah. "Kajian Yuridis Penyelesaian Sengketa Perbankan Syariah". Jurnal Legislasi. Vol. 10 No. 3. September 2013. Jakarta: DJPP of Justice and Human Rights Ministry;

Lindsey, Tim. "Between Piety and Prudence: State Syariah and the Regulation of Islamic Banking in Indonesia". Sydney Law Review. Vol. 34 No. 107. 2012. Sydney: Sydney Law School-the University of Sydney;

Mansyur, Ali. "Aspek Hukum Perbankan Syariah dan Implementasinya di Indonesia". Jurnal Dinamika Hukum. Vol. 11 Special Edition. 2011. Purwokerto: Law Faculty of Universitas Jenderal Soedirman;

Podgorecki, Adam dan Christopher J. Whelan "So-ciological Approaches to Law". Translated by Rnc. Widyaningsih and Kartasapoetra. 1987. Pendekatan Sosiologis Terhadap Hukum. Jakarta: Bina Aksara;

Rahmawati, Etika. "Telaah terhadap Asas Personalitas Keislaman Dikaitkan dengan Teori Receptio in Complexu". Gloria Yuris. Vol 1 No. 2. 2013. Jakarta: Universitas Katolik Atma jaya;

Soekanto, Soerjono. 1985. Perspektif Teoritis Studi Hukum dalam Masyarakat. Jakarta: Rajawali;

Superman, Eman. "Perkembangan Doktrin Penyelesaian Sengketa di Indonesia"; Jurnal Penegakan Hukum. Vol. 3 No. 2. July 2006. Bandung: Law Division of Law Faculty of Universitas Padjadjaran;

Zaman, M Raquibuz and Hormoz Movassaghi. Islamic Banking A Performance Analysis “. The Journal of Global Business . Vol. 12. No. 22. Spring 2001. 